\title{
Pseudopaludicola ternetzi (Anura: Leiuperidae): two lectotypes for the same taxon
}

\author{
DARIO CARDOZO ${ }^{1,2,4}$ \& DIEGO BALDO ${ }^{1,3}$ \\ ${ }^{\prime}$ Laboratorio de Genética Evolutiva, Departamento de Genética, Universidad Nacional de Misiones, Argentina \\ ${ }^{2}$ Consejo Nacional de Investigaciones Científicas y Técnicas (CONICET). \\ ${ }^{3}$ Instituto de Herpetología, Fundación Miguel Lillo, Miguel Lillo 251, CP: 4000 San Miguel de Tucumán, Argentina \\ ${ }^{4}$ Corresponding author.E-mail: darcardz@gmail.com
}

Pseudopaludicola ternetzi was described on the basis of an undefined number of syntypes, but involving males and females (Miranda-Ribeiro 1937). Since Miranda-Ribeiro described this species, several taxonomic considerations were made on it. First, Bokermann (1966) considered P. ternetzi as a synonym of P. ameghini (Cope 1887), without giving any evidence to support this decision. Although some authors followed this proposal (like Gallardo 1968), others continued considering P. ternetzi as a good species (e.g., Frost 1985; Lynch 1989). Haddad and Cardoso (1987) provided bioacustic and morphometric evidence to consider P. ameghini as a junior synonym of P. mystacalis (Cope 1887). In 1996, Lobo reviewed the type specimens of $P$. ameghini, $P$. mystacalis, and $P$. saltica described by Cope (1887) and housed at the ANSP (Academy of Natural Sciences of Philadelphia), and redescribed P. ternetzi based on four vouchers collected by Dr. Ternetz in December of 1923, deposited in the Museu Nacional, Rio de Janeiro, Brazil (MNRJ). In coincidence with Haddad and Cardoso (1987), Lobo (1996) considered P. ameghini as a junior synonym of P. mystacalis, assigned a lectotype for P. ternetzi (MNRJ 5462, male), and designated as paralectotypes the vouchers MNRJ 477, MNRJ 5460, and MNRJ 5461 (all females). Lobo choose the only male syntype examined by him as lectotype considering that the detailed description by Miranda-Ribeiro (1937) of a male matched with the size and morphology of this specimen, while only reported some details of a female. Such taxonomic decision was based on the article 74 of the International Code of Zoological Nomenclature (ICZN 1985).

Without making reference to Lobo (1996) but relying on the database of Frost (2011) which did not report on this lectotype designation, Caramaschi and Pombal Jr. (2011) recently designated a different specimen as lectotype for $P$. ternetzi (MNRJ 5460, female) and other specimens as paralectotypes (MNRJ 445, MNRJ 5442; MNRJ 5461-5462). However, as stated in article 74.1 .3 of the ICZN (1999): "The valid designation of a lectotype permanently deprives all other specimens that were formerly syntypes of that nominal taxon of the status of syntype [Art. 73.2.2]; those specimens then become paralectotypes". Consequently the valid lectotype of P. ternetzi is the voucher male specimen MNRJ 5462, and the female specimens referred by Lobo (1996), MNRJ 477, MNRJ 5460, MNRJ 5461, are paralectotypes. Finally, the article 61.1.3. of the ICZN (1999) states that "Once fixed, name-bearing types are stable and provide objective continuity in the application of names. Thus the name-bearing type of any nominal taxon, once fixed in conformity with the provisions of the Code, is not subject to change..."

In conclusion, the specimen MNRJ 5462 is actually the lectotype for Pseudopaludicola ternetzi Miranda-Ribeiro, 1937, as designated by Lobo (1996). The specimen MNRJ 5460, erroneously designated lectotype for the same species by Caramaschi and Pombal Jr. (2011), is actually a paralectotype. Besides the specimens referred by Lobo (1996) as paralectotypes, all other specimens traced by Caramaschi and Pombal Jr. (2011) were correctly designated paralectotypes. The type locality for the species was updated and correctly defined by Caramaschi and Pombal Jr. (2011).

We thank E. Lavilla, J. Faivovich, G. Scrocchi, U. Caramaschi and C. Borteiro for corrections and comments on the manuscript. We thank CONICET, Instituto de Herpetología - Fundación Miguel Lillo, and the following funds: PICT 06223, 07-2202 (ANPCyT), PIP 11120080102422 (CONICET), CIUNT-G430 (UNT). 


\section{References}

Bokermann, W.C.A. (1966) Lista Anotada das Localidades Tipo de Anfíbios Brasileiros. Serviço de Documentação RUSP, São Paulo. 183 pp.

Caramaschi, U. \& Pombal Jr. J.P. (2011) The type series of Pseudopaludicola ternetzi Miranda-Ribeiro, 1937 (Anura, Leiuperidae) with designation of a lectotype. Zootaxa, 3051, 62-64.

Cope, E.D. (1887) Synopsis of the Batrachia and Reptilia obtained by H. H. Smith, in the Province of Mato Grosso, Brazil. Proceedings of the American Philosophical Society, 24, 44-60.

Frost, D.R. (1985) Amphibians Species of the World. Allen Press, Inc., and the Association of Systematics Collections, $732 \mathrm{pp}$.

Frost, D.R. (2011) Amphibian Species of the World: an Online Reference. Version 5.5 (31 January, 2011). Electronic Database accessible at http://research.amnh.org/vz/herpetology/amphibia/ American Museum of Natural History, New York, USA (Accessed 03 November 2011).

Gallardo, J.M. (1968) Observaciones biológicas sobre Pseudopaludicola falcipes (Hensel) (Anura: Leptodactylidae). Ciencia e Investigación, 24, 411-419.

Haddad, C.F.B. \& Cardoso, A. J. (1987) Taxonomia de três espécies de Pseudopaludicola (Anura, Leptodactylidae). Papéis Avulsos de Zoologia, 36, 287-300.

ICZN - International Commission on Zoological Nomenclature (1985) International Code of Zoological Nomenclature. The International Trust for Zoological Nomenclature, London. $\mathrm{xx}+338 \mathrm{pp}$.

ICZN - International Commission on Zoological Nomenclature (1999) International Code of Zoological Nomenclature. The International Trust for Zoological Nomenclature, London. xxx + 306 pp.

Lobo, F. (1996) Evaluación del status taxonómico de Pseudopaludicola ternetzi Miranda Ribeiro, 1937; P. mystacalis y P. ameghini (Cope, 1887). Osteología y distribución de las especies estudiadas. Acta Zoológica Lilloana, 43, $327-$ 346.

Lynch, J. (1989) A review of the leptodactylid frogs of the genus Pseudopaludicola in Northern South America. Copeia, 577-588.

Miranda-Ribeiro, A. (1937) Alguns batrachios novos das colecções do Museu Nacional. O Campo, maio, 66-69. 